\title{
HYDROCHEMICAL CLASSIFICATION OF AMAZONIAN RIVERS: A SYSTEMATIC REVIEW AND META-ANALYSIS
}

\author{
Eduardo Antonio Ríos-Villamizar \\ Instituto Nacional de Pesquisas da Amazônia - INPA/MCTIC \\ Programa de Grande Escala da Biosfera-Atmosfera na Amazônia - LBA \\ Coordenação de Pesquisas Hidrológicas - $\mathrm{CPH}$ \\ Programa de Pós-Graduação em Clima e Ambiente - PPG-CLIAMB \\ eduardorios17@hotmail.com \\ J. Marion Adeney \\ Center for Energy, Environment and Sustainability \\ Gordon and Betty Moore Foundation \\ marion.adeney@gmail.com \\ Maria Teresa Fernandez Piedade \\ Instituto Nacional de Pesquisas da Amazônia - INPA/MCTIC \\ Ecologia, Monitoramento e Uso Sustentável de Áreas Úmidas - MAUA \\ maitepp@inpa.gov.br \\ Wolfgang Johannes Junk \\ Instituto Nacional de Ciência e Tecnologia em Áreas Úmidas (INCT-INAU-UFMT) \\ wij@evolbio.mpg.de
}

\begin{abstract}
Water and soil chemistry provide important parameters for the study of river ecology and biogeochemical cycles. Furthermore, they determine management options of rivers and connected wetlands. The first scientific classification of Amazonian water bodies was elaborated in the 1950s by Harald Sioli. He used water color, as well as physical and chemical parameters, to explain limnological characteristics of the large Amazonian rivers and related these characteristics to the geological and geomorphological properties of their catchments. Today, an increasing amount of hydrochemical data indicate that the chemical composition of Amazonian water bodies varies much more than assumed by Sioli. Nevertheless, his simplified classification is useful for describing the natural physical and chemical variability of Amazonian rivers and wetlands. The electrical conductivity, $\mathrm{pH}$-value and the distribution of major cations and anions allow to distinguish well among the three classical water types (white, black and clear) and to categorize other water bodies as intermediate types, in order to subsidize a more detailed classification system of Amazonian fresh waters. This classification indicates in lower order tributaries the existence of many transitional hydrochemical stages and the change in water quality between rainy and dry seasons. These differences have to be considered in the general Brazilian and Amazonian wetland classification systems in order to formulate recommendations for their sustainable management.
\end{abstract}

Keywords: Amazon basin. Water quality. River water types.

\section{CLASSIFICAÇÃO HIDROQUÍMICA DE RIOS DA AMAZÔNIA: UMA REVISÃO SISTEMÁTICA E META-ANÁLISE}

\begin{abstract}
RESUMO
A qualidade química da água proporciona parâmetros fundamentais para o estudo da ecologia dos rios, sua biodiversidade e seus ciclos biogeoquímicos. Esses parâmetros determinam opções de gestão dos rios e das áreas úmidas associadas. A primeira classificação científica dos corpos da água da Amazônia foi elaborada pelo pesquisador Harald Sioli em meados do século passado (1950s). Ele estabeleceu 3 tipos de água: água branca, água preta e água clara. Com esta tipologia ele explicou peculiaridades limnológicas dos grandes rios da Amazônia. Além disso, ele relacionou os fatores físicoquímicos dos três tipos de águas com as propriedades geológicas e geomorfológicas das
\end{abstract}

$\begin{array}{lllll}\text { Caminhos de Geografia } \quad \text { Uberlândia-MG } & \text { v. 21, n. } 78 \quad \text { Dez/2020 } & \text { p. 211-226 Página } 211\end{array}$ 


\begin{abstract}
suas bacias hidrográficas. Atualmente uma quantidade crescente de dados hidro-químicos indicam que a composição dos corpos da água na Amazônia varia mais do que foi assumido por Sioli. Nesta pesquisa, foram usados os dados disponíveis na literatura sobre as variáveis transparência, $\mathrm{pH}$, condutividade elétrica e a distribuição de cátions e ânions principais para reavaliar a antiga classificação. Esta análise permitiu distinguir os três tipos de água clássicos e categorizar outros corpos de água em tipos intermediários, a fim de subsidiar um sistema de classificação mais detalhado para as águas Amazônicas. Esta classificação indica, nos afluentes de ordem inferior, a existência de muitos estágios hidroquímicos de transição e a mudança na qualidade da água entre as estações chuvosa e seca. Essas diferenças devem ser consideradas nos sistemas gerais de classificação de áreas úmidas brasileiras e amazônicas para formular recomendações para seu manejo sustentável.
\end{abstract}

Palavras-chave: Bacia Amazônica. Qualidade da água. Tipos de água dos rios.

\title{
INTRODUCTION
}

Chemical composition of water and sediments are important parameters for the ecology of river systems. It ranks, after climate and hydrology, third in importance for wetlands classification because of its fundamental importance for life in water and wetlands. Chemical content influences not only the occurrence of organisms but also primary and secondary production. Water and soil chemistry provide important parameters for biogeochemical cycles and determine management options. Pre-Columbian populations categorized Amazonian rivers by the color of their water. This criterion was adopted by European immigrants and is evident today in names like Rio Claro, Rio Preto, Rio Negro, Rio Branco, and Rio Verde (Clear River, Black River, Black River, White River, and Green River, respectively). Native and colonial inhabitants of the Amazon knew that water color was related to specific ecological properties such as fish richness, soil fertility, or mosquito abundance (JUNK et al., 2011).

The first scientific classification of Amazonian water bodies was elaborated in the 1950s by Sioli (1956). He used water color, transparency, $\mathrm{pH}$ and electrical conductance to explain limnological characteristics of the large Amazonian rivers. The innovative aspect of his classification was the correlation of these characteristics to the geological and geomorphological properties of the river catchments, an approach used today in landscape ecology.

Whitewater rivers (such as the Amazon main course and the Juruá, Japurá, Purus, and Madeira) are turbid, with water transparency (Secchi depth) that varies between 20 and $60 \mathrm{~cm}$, and have their origins in the Andes, from which they transport large amounts of nutrient-rich sediments. Their waters have near-neutral $\mathrm{pH}$ and relatively high concentrations of dissolved solids indicated by the electric conductivity that varies between $30-140 \mu \mathrm{S} \mathrm{cm}^{-1}$. Electric conductivity of the Amazon River decreases from the Andes in the West to the mouth in the East by dilution through tributaries with electrolyte-poor clear and black waters, originating from the Precambrian Shields in the North and South of the central Amazon basin. Near the Andes it is about $120-140 \mu \mathrm{S} \mathrm{cm}^{-}{ }^{-}$, at the lower course about $30-50 \mu \mathrm{S} \mathrm{cm}-1$ during the wet and dry season, respectively (GIBBS, 1967). Near the coast, electric conductivity can rise because of entrance of marine water and aerial salt deposition (JUNK et al., 2012). Whitewater rivers deposit their sediments in large fringing floodplains that are locally called várzeas.

Blackwater rivers (such as the Negro River) drain the Precambrian Guiana shield, which is characterized by large areas of white sands (podzols). Their water transparency is about $60-120 \mathrm{~cm}$, with low quantities of suspended matter but with high amounts of humic acids that give the water a brownish-reddish color. The $\mathrm{pH}$ values of such rivers are in the range of 4-5 and their electrical conductivity is $<20 \mu \mathrm{S} \mathrm{cm}$. The floodplains of blackwater rivers are of low fertility and are locally called igapós. Clearwater rivers (such as the Tapajós and Xingu rivers) have their upper catchments in the Cerrado region of the Central Brazilian archaic shield. The transparency of their greenish waters is above $150 \mathrm{~cm}$, with low amounts of sediments and dissolved solids and $\mathrm{pH}$ that varies between 6 and 7 in large rivers. Electrical conductivity in large rivers is in the range of $10-20 \mu \mathrm{S} \mathrm{cm}^{-1}$. The floodplains of clearwater rivers are of intermediate fertility and also called igapós. 
This simplified classification has dominated until today the scientific discussion about limnology and ecology of the Amazon basin. But Sioli's classification was based only on a very limited data base, because, at his time, the access to the vast river basin was restricted to the large rivers, which he visited by small vessels or by canous driven by small outboard motors. Roads, which give today access to interfluvial parts of the basin and allow hydrochemical transects were not available and the geological maps only provided a large-scale simplified view of the basin. Also water-chemical analyses in Amazonia were in their beginnings and Sioli had no lab-facilities at disposal, concentrating his studies mainly on $\mathrm{pH}$, electric conductance, transparency, and water colour.

In the meantime, the situation has changed dramatically. The National Amazon Research Institute has developed from a small laboratory during Sioli's time to a large research institution of international reputation, which conducted many limnological studies and hosted high-level, national and international limnological projects (SIOLI, 1968; STALLARD and EDMOND, 1983; FURCH, 1986; FURCH and JUNK, 1997; GAILLARDET et al., 1997; RICHEY et al., 2008; FIGUEIREDO et al., 2010).

The aim of this paper is to (1) establish and analyze a comprehensive data base about water chemistry of Amazonian rivers and streams, (2) provide new insights in the limnological classification of Amazonian rivers and streams, and their connected wetlands (JUNK et al., 2012).

\section{MATERIAL AND METHODS}

From literature (RÍOS-VILLAMIZAR, 2013; RíOS-VILLAMIZAR et al., 2014, 2016, 2020a, 2020b; SILVA et al., 2019) we collected data available on hydrochemistry of rivers and streams (Figure 1 and Appendix). For that purpose the web sites of Science Direct, Google Scholar, Springer Link and Scielo, among others, were consulted. We did not consider limnological data on floodplain lakes, because lake-internal biological and physico-chemical processes can dramatically modify limnological parameters in comparison to the parent rivers. Acid-washed polyethylene bottles were used for collecting water samples on the main channel of the river basins as well as on principal tributaries and small streams (igarapés) in the course of four field surveys during 2009-2010 at the lower sections of the Jutaí, Juruá, Tefé and Tapajós rivers $(n=42)$. The bottles were rinsed with the water being collected and the samples were manually collected beneath the water surface.

All the samples were kept cool until the time of the analysis. Water samples were filtered through Whatman GF/F fiberglass filters $(0.7 \mu \mathrm{m})$. The transparency $(\mathrm{m})$ values were measured using the Secchi disk, the electrical conductivity $\left(\mu \mathrm{S} \mathrm{cm}{ }^{-1}\right.$ at $\left.25^{\circ} \mathrm{C}\right)$, and $\mathrm{pH}$ values were measured in the field using WTW instruments. In the laboratory of the INPA in Manaus (Brazil) were analyzed the water samples to obtain the values of the major cations such as $\mathrm{Ca}\left(\mathrm{mg} \mathrm{l}^{-1}\right), \mathrm{Mg}\left(\mathrm{mg} \mathrm{l}^{-1}\right), \mathrm{Na}\left(\mathrm{mg} \mathrm{l}^{-1}\right)$ and $\mathrm{K}$ $\left(\mathrm{mg} \mathrm{l}^{-1}\right)$, and major anions such as Alkalinity $\left(\mathrm{mg} \mathrm{HCO}_{3} \mathrm{l}^{-1}\right), \mathrm{SO}_{4}\left(\mathrm{mg} \mathrm{l}^{-1}\right)$ and $\mathrm{Cl}\left(\mathrm{mgl}^{-1}\right)$, as well as the

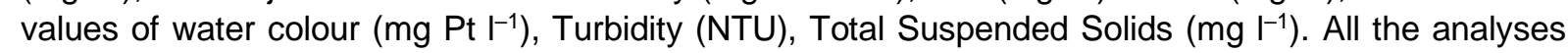
were carried out by standard methods (APHA, 2005). We used the data of 380 rivers and streams for our analysis $\left(n_{\text {total }}=1008\right)$. To better differentiate the water types, we established 6 categories: White water, black water, clear water, intermediate type $A$, intermediate type $B$, and brackish water. For the establishment of these categories we used suspended sediment load, $\mathrm{pH}$, electric conductivity, and the relationship between alkali and alkali-earth metals and major anions. The establishment of these categories is discussed later and the value of the parameters for the classification is described by Ríos-Villamizar et al. (2020b). In order to assess the water typologies, a one-way ANOVA were employed for data reduction and sample classification, following established procedures. Tukey $95 \%$, simultaneous confidence intervals, and all pairwise comparisons among levels of category using Minitab 14. 
Figure 1 - Water physicochemistry sampling sites in the Amazon Basin. Dots show the locations of samples, colored by water type. Also shown are the amount of studies per river basin and river order. The vast majority of studies (count $=299$ ) were carried out along the main stem of the Solimões/Amazon, Negro, Madeira and Tocantins rivers. The vast majority of rivers has fewer than 10 samples or remains unrepresented in the literature. River basins (shown is level 3) and river order are from Venticinque et al. (2016).

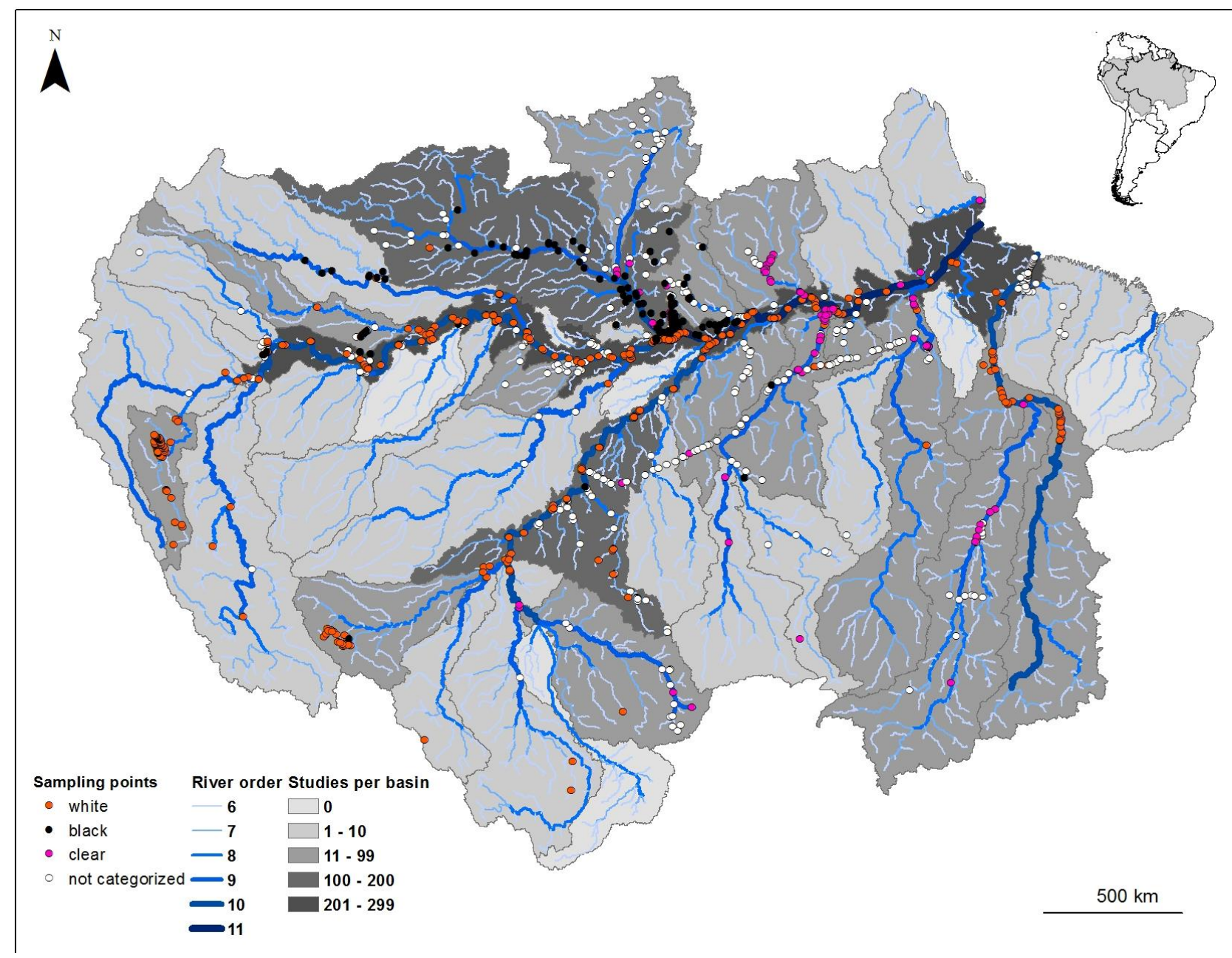

Source - Modified from Ríos-Villamizar et al. (2020a).

\section{RESULTS AND DISCUSSION}

The analysis of all the hydrochemical data shows a complex pattern, which at the first glance, seem to make a classification difficult, as shown for the parameters transparency plotted against conductivity, $\mathrm{pH}$, the proportions of major cations (alkali and alkaline-earth metals) and major anions. When all the data is plotted together, we can notice a separation between white water and black water types whereas clearwater and intermediate types are covering a wide range of variability, overlapping in some parameters with white and black waters (Figures 2-3). 
Figure 2 - Relationship between $\mathrm{pH}$ value and transparency of Amazonian rivers and streams. The ellipses indicate the position of the typical white (orange), black (black) and clear (blue) waters, according to RíosVillamizar et al. (2020b).

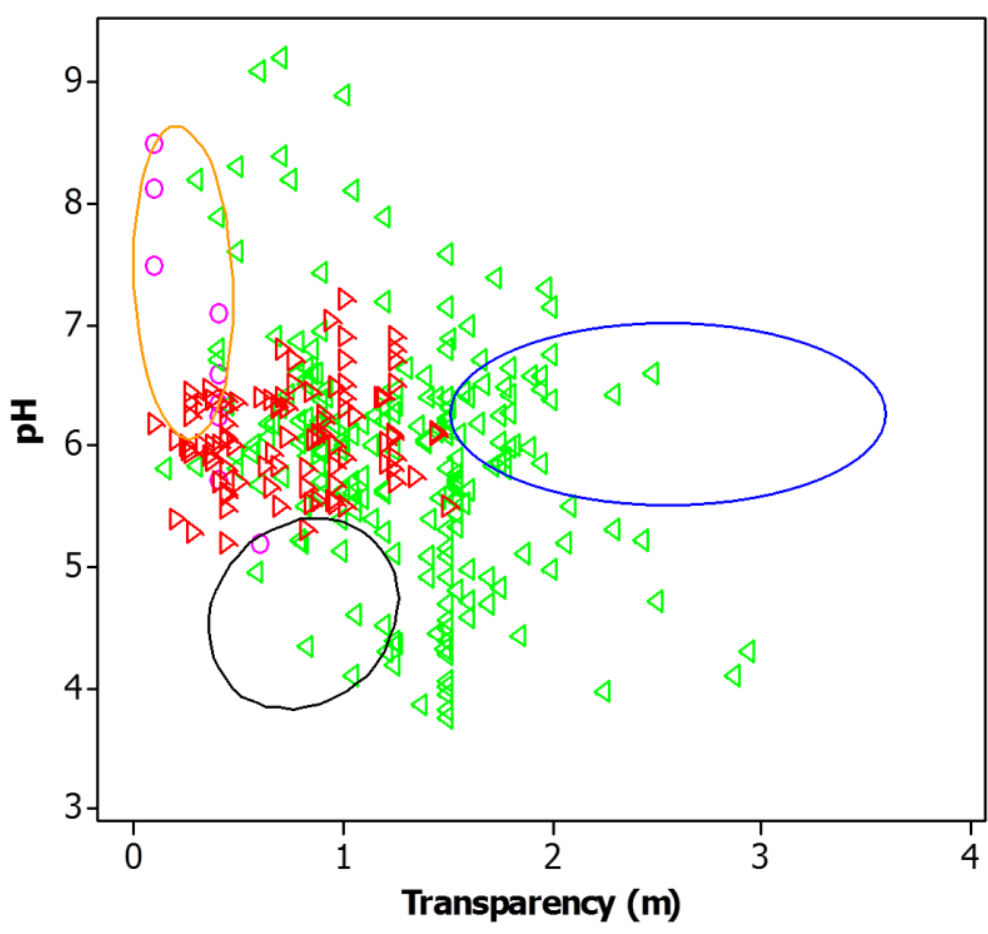

\begin{tabular}{|ll|}
\hline \multicolumn{1}{|c|}{ Category } \\
black \\
0 brackish \\
dear \\
$\triangleleft$ & Intermediate type A \\
$\triangleright$ & Intermediate type B \\
& white \\
\hline
\end{tabular}

Source - Research Data.

Figure 3 - Relationship between the content of alkali and alkaline-earth metals and transparency of Amazonian rivers and streams. The ellipses indicate the position of the typical white (orange), black (black) and clear (blue) waters, after Ríos-Villamizar et al. (2020b).
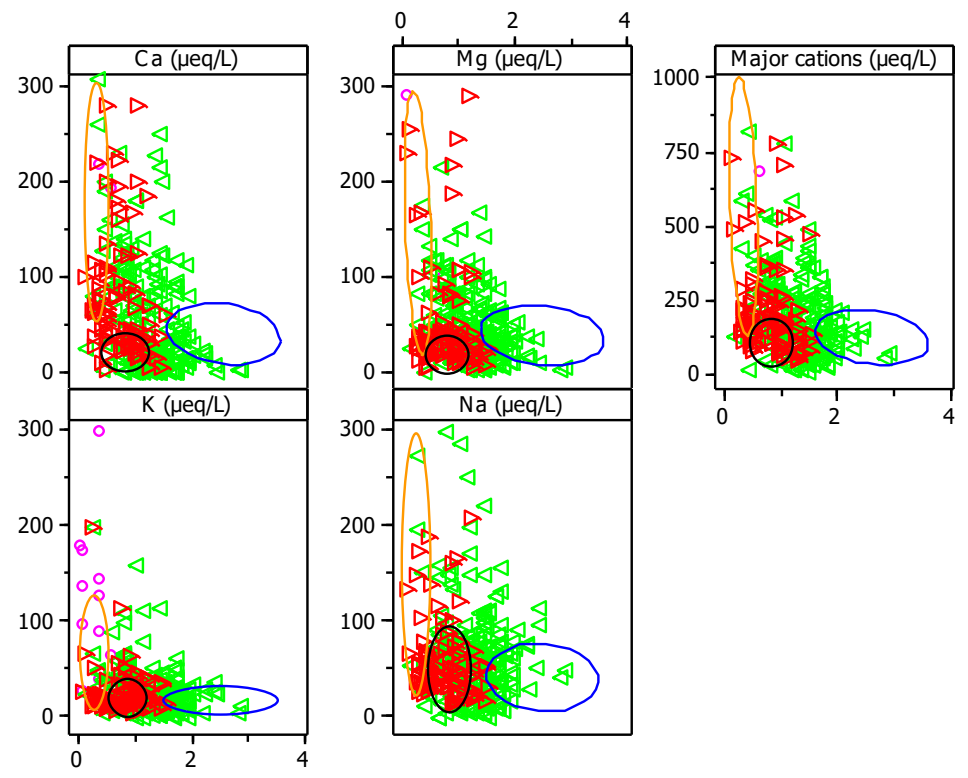

Category black

O brackish clear

$\triangleleft$ Intermediate type A

$\triangleright$ Intermediate type $B$ white

Transparency (m)

Source - Research Data. 
Furthermore, annual data sets show for some rivers considerable fluctuations in physico-chemical parameters, which makes the relation to a specific water type difficult, as shown for the Branco, Iça, Japurá, Javari and Purus rivers (Figures 4-5).

Figure 4 - Water level fluctuations and seasonal variations of $\mathrm{pH}$-values in the Branco River at Caracarai. Monthly mean values from September 2003 to December 2009.

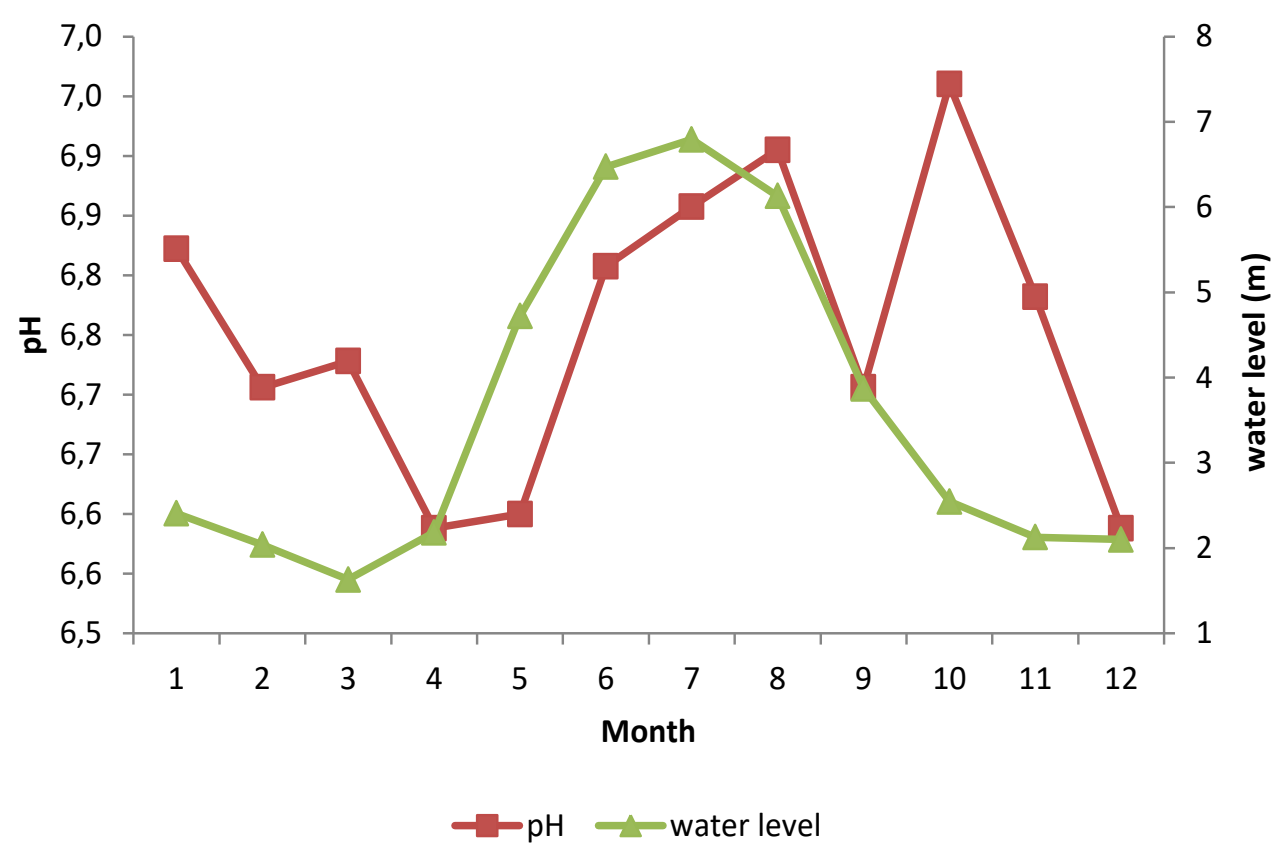

Source - Research data according to ORE-HYBAm.

Figure 5 - Maximum, mean and minimum values of electrical conductivity $(\mu \mathrm{S} / \mathrm{cm})$ for Iça, Japurá, Javari and Purus rivers.

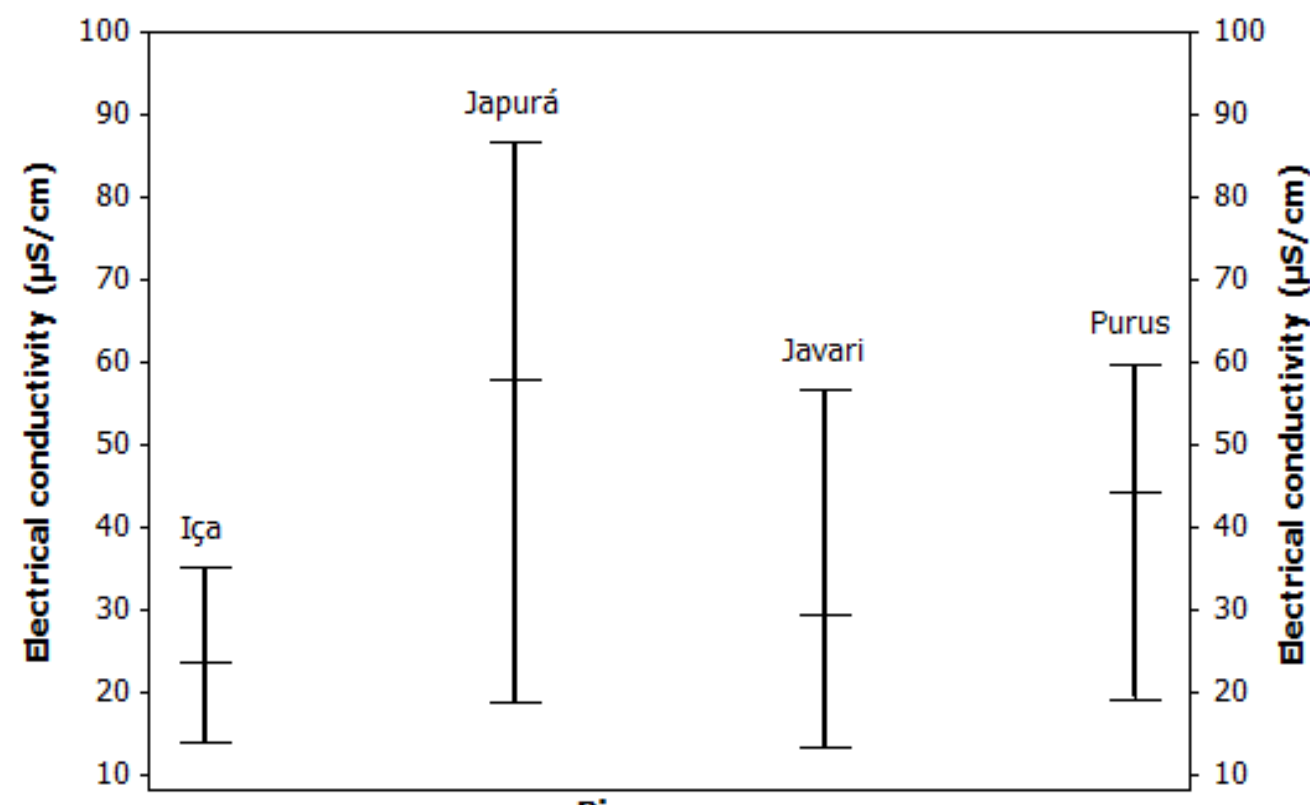

River name

Source - Research Data. 
However, a classification is necessary for the discussion of ecological ecosystem peculiarities such as species diversity and distribution, biomass, primary and secondary production and decomposition, and management options in the water and associated wetlands. A classification is also required for a landscape ecology approach because water chemistry of river water represents the chemical conditions in the respective catchment. Therefore, we tried to separate typical whitewater, blackwater, and clearwater rivers, according to the criteria given by Sioli, slightly modified by us, and added 3 other categories. The criteria are given in Table 1.

Of the 380 rivers and streams analyzed, 193 could be addressed to Sioli's categories: 105 whitewater rivers, 76 black-water rivers and 12 clearwater rivers (Appendix). They can be clearly separated with respect to the parameters $\mathrm{pH}$, conductivity, the proportions and contents of major cations and major anions. The $\mathrm{pH}$-value that is considered the key parameter of the analysis which also permits to classify electrolyte-poor rivers, showing similar electrical conductivity values, into the blackwater or clearwater categories. Nevertheless, it is noticeable that the black-water and clearwater rivers still exhibit some overlaying areas when the parameters electrical conductivity, the proportions of major cations and major anions are plotted against transparency. It could be explained because in electrolyte-poor waters, such as the typical blackwaters and clearwaters, the ionic composition can have significant changes in function of small oscillations of the ionic content (Figures 2-3).

In our analysis, in order to obtain a robust classification system, all available data were collected. The data for the different categories were not presented in relation to seasonality, but considering the margin of variability. We did it because the objective of this work was not to analyze the seasonal or spatial variability, which has already been done by the authors of the different studies compiled. Instead, our goal was to establish a more flexible system of water type categories in the Amazon, allowing for the inclusion of as many rivers and streams as possible. In addition, we intend to highlight and describe the range of variability of the different parameters used for this classification.

The ANOVA analysis of electrical conductivity $(\mu \mathrm{S} / \mathrm{cm})(\mathrm{F}=130.01), \mathrm{pH}(\mathrm{F}=218.48)$, transparency $(\mathrm{m})$ $(F=188.78)$, major anions $(\mu \mathrm{eq} / \mathrm{L})(\mathrm{F}=101.34)$, and major cations $(\mu \mathrm{eq} / \mathrm{L})(\mathrm{F}=83.44)$ versus category showed significant separation $(\mathrm{P}<0.05)$ of the water typologies. 
Table 1 - Physicochemical and chemical parameters of Amazonian river types ( $\mathrm{SD}=$ standard deviation; $n=$ number of samples; $\mathrm{N}_{\mathrm{t}}=\mathrm{n}_{\text {total }}$ by parameter).

\begin{tabular}{|c|c|c|c|c|c|c|c|c|c|c|c|c|c|c|c|c|c|c|c|}
\hline Parameter & & Vhitewater & & & ckwater & & $\mathrm{Cl} \epsilon$ & arwater & & Interm & diate typ & A & InterI & nediate type & & $\mathrm{Br}$ & ckish water & & \\
\hline & Range & Mean $\pm S D$ & $\mathrm{n}$ & Range & $\begin{array}{l}\text { Mean } \pm \\
\text { SD }\end{array}$ & $\mathrm{n}$ & Range & $\begin{array}{l}\text { Mean } \pm \\
\text { SD }\end{array}$ & $\mathrm{n}$ & Range & $\begin{array}{l}\text { Mean } \pm \\
\text { SD }\end{array}$ & $n$ & Range & Mean $\pm S D$ & $n$ & Range & Mean $\pm S D$ & $\mathrm{n}$ & $\mathrm{N}_{\mathrm{t}}$ \\
\hline $\mathrm{pH}$ & $6-8.5$ & $7.004 \pm 0.46$ & 358 & $3.6-5.5$ & $4.8 \pm 0.4$ & 108 & $\begin{array}{l}5.35- \\
7.21\end{array}$ & $6.4 \pm 0.4$ & 94 & $\begin{array}{l}3.75- \\
9.20\end{array}$ & $\begin{array}{c}5.9 \pm 1.0 \\
3\end{array}$ & 213 & $5.2-7.2$ & $6.1 \pm 0.4$ & 101 & $\begin{array}{l}5.2- \\
8.50\end{array}$ & $7.1 \pm 1.14$ & 11 & $\begin{array}{c}88 \\
5\end{array}$ \\
\hline $\begin{array}{l}\text { Electric } \\
\text { conductivity } \\
(\mu \mathrm{S} / \mathrm{cm})\end{array}$ & $30-760$ & $\begin{array}{c}118.65 \pm 10 \\
7.1\end{array}$ & 264 & $3.75-28$ & $\begin{array}{c}12.2 \pm 5 \\
1\end{array}$ & 95 & $\begin{array}{l}5.10- \\
53.6\end{array}$ & $\begin{array}{c}16.7 \pm 9 \\
6\end{array}$ & 96 & $\begin{array}{c}1.18- \\
140.89\end{array}$ & $\begin{array}{c}18.9 \pm 1 \\
8.9\end{array}$ & 200 & $\begin{array}{l}0.01- \\
190.7\end{array}$ & $21.9 \pm 25.6$ & 91 & $\begin{array}{l}358.3- \\
7171.9\end{array}$ & $\begin{array}{c}2178.9 \pm 23 \\
54.4\end{array}$ & 11 & $\begin{array}{l}75 \\
7\end{array}$ \\
\hline $\begin{array}{l}\text { Transparency } \\
\text { (m) }\end{array}$ & $\begin{array}{l}0.1- \\
2.35\end{array}$ & $0.43 \pm 0.43$ & 450 & $0.2-1.7$ & $\begin{array}{c}0.99 \pm 0 . \\
2\end{array}$ & 113 & $\begin{array}{l}0.35- \\
3.55\end{array}$ & $1.6 \pm 0.6$ & 99 & $\begin{array}{c}0.155- \\
2.94\end{array}$ & $1.3 \pm 0.5$ & 233 & $0.04-1.5$ & $0.74 \pm 0.35$ & 102 & $\begin{array}{c}0.05- \\
0.6\end{array}$ & $0.28 \pm 0.19$ & 11 & $\begin{array}{l}10 \\
08\end{array}$ \\
\hline $\begin{array}{l}\text { Water colour } \\
\text { (mg/Pt/L) }\end{array}$ & $17-284$ & $97.8 \pm 55.8$ & 131 & $\begin{array}{c}28.5- \\
627\end{array}$ & $\begin{array}{l}148.4 \pm \\
122.01\end{array}$ & 54 & $\begin{array}{c}2.77- \\
193\end{array}$ & $\begin{array}{c}51.2 \pm 5 \\
7.9\end{array}$ & 27 & $1-204$ & $\begin{array}{c}40.5 \pm 3 \\
5.02\end{array}$ & 57 & $13-190$ & $72.7 \pm 53.6$ & 39 & $19-75$ & $42.03 \pm 18.5$ & 8 & $\begin{array}{c}31 \\
6\end{array}$ \\
\hline $\begin{array}{l}\text { Humic } \\
\text { substances } \\
\text { (mg/L) }\end{array}$ & $0.18-18$ & $7.9 \pm 7.1$ & 34 & 2.3-71 & $\begin{array}{c}25.2 \pm 1 \\
6.02\end{array}$ & 33 & $7.8-11$ & $9.3 \pm 1.4$ & 4 & $1.73-36$ & $\begin{array}{c}13.1 \pm 6 . \\
5\end{array}$ & 29 & $\begin{array}{l}1.02- \\
28.9\end{array}$ & $15.6 \pm 6.9$ & 14 & - & - & - & $\begin{array}{c}11 \\
4\end{array}$ \\
\hline $\begin{array}{l}\text { Major cations } \\
(\mu \mathrm{eq} / \mathrm{L})\end{array}$ & $\begin{array}{l}131.9- \\
7916.8\end{array}$ & $\begin{array}{c}939.3 \pm 879 \\
7\end{array}$ & 401 & $\begin{array}{c}7.4- \\
528.7\end{array}$ & $\begin{array}{c}67.3 \pm 6 \\
4.2\end{array}$ & 113 & $\begin{array}{l}45.1- \\
432.8\end{array}$ & $\begin{array}{c}169.8 \pm \\
73.8\end{array}$ & 99 & $\begin{array}{c}7.04- \\
1855.8\end{array}$ & $\begin{array}{c}194.3 \pm \\
185.2\end{array}$ & 231 & $\begin{array}{c}44.5- \\
2773.7\end{array}$ & $\begin{array}{c}264.4 \pm 336 \\
9\end{array}$ & 102 & $\begin{array}{c}681.3- \\
77203 . \\
04\end{array}$ & $\begin{array}{c}17808.2 \pm 2 \\
6056.8\end{array}$ & 11 & $\begin{array}{c}95 \\
7\end{array}$ \\
\hline $\mathrm{Ca}(\mu \mathrm{eq} / \mathrm{L})$ & $\begin{array}{l}53.9- \\
4126.7\end{array}$ & $\begin{array}{c}560.7 \pm 540 \\
9\end{array}$ & 401 & $0-103.3$ & $\begin{array}{c}13.4 \pm 1 \\
5.7\end{array}$ & 113 & $\begin{array}{c}0- \\
219.15\end{array}$ & $\begin{array}{c}42.8 \pm 4 \\
1.1\end{array}$ & 99 & $0-918.2$ & $\begin{array}{c}53.2 \pm 8 \\
0.8\end{array}$ & 231 & $\begin{array}{c}1.99- \\
973.05\end{array}$ & $\begin{array}{c}113.1 \pm 152 \\
6\end{array}$ & 102 & $\begin{array}{c}193.1- \\
16546 . \\
9\end{array}$ & $\begin{array}{c}3291.1 \pm 48 \\
64.4\end{array}$ & 11 & $\begin{array}{c}95 \\
7\end{array}$ \\
\hline $\mathrm{Mg}(\mu \mathrm{eq} / \mathrm{L})$ & $\begin{array}{c}16.4- \\
2799.4\end{array}$ & $159.6 \pm 182$ & 401 & $0-131.7$ & $\begin{array}{c}12.7 \pm 1 \\
5.2\end{array}$ & 113 & $\begin{array}{l}9.05- \\
137.8\end{array}$ & $\begin{array}{c}46.2 \pm 2 \\
5.6\end{array}$ & 99 & $0-814.6$ & $\begin{array}{c}50.7 \pm 6 \\
5.3\end{array}$ & 231 & $3.7-288$ & $48.7 \pm 56.5$ & 102 & $\begin{array}{l}102.8- \\
5318.9\end{array}$ & $\begin{array}{c}1195.8 \pm 14 \\
54.9\end{array}$ & 11 & $\begin{array}{c}95 \\
7\end{array}$ \\
\hline $\mathrm{K}(\mu \mathrm{eq} / \mathrm{L})$ & $\begin{array}{c}5.7- \\
207.9\end{array}$ & $32.9 \pm 22.02$ & 401 & $0-168.8$ & $\begin{array}{c}13.1 \pm 2 \\
0.2\end{array}$ & 113 & $0-46.04$ & $\begin{array}{c}19.4 \pm 8 . \\
2\end{array}$ & 99 & $0-199.5$ & $\begin{array}{c}25.3 \pm 2 \\
4.5\end{array}$ & 231 & $\begin{array}{c}4.9- \\
413.1\end{array}$ & $28.5 \pm 44.9$ & 102 & $\begin{array}{l}27.1- \\
298.9\end{array}$ & $125.1 \pm 76.6$ & 11 & $\begin{array}{c}95 \\
7\end{array}$ \\
\hline $\mathrm{Na}(\mu \mathrm{eq} / \mathrm{L})$ & $\begin{array}{c}4.3- \\
3871.3\end{array}$ & $\begin{array}{c}186.05 \pm 26 \\
2.1\end{array}$ & 401 & $\begin{array}{c}4.3- \\
382.8\end{array}$ & $\begin{array}{c}28.02 \pm \\
40.2\end{array}$ & 113 & $\begin{array}{l}8.7- \\
159.2\end{array}$ & $\begin{array}{c}61.3 \pm 3 \\
0.6\end{array}$ & 99 & $0-654.6$ & $\begin{array}{c}65.1 \pm 6 \\
7.2\end{array}$ & 231 & $\begin{array}{c}13.3- \\
1099.6\end{array}$ & $74.1 \pm 127.9$ & 102 & $\begin{array}{l}320.3- \\
71400\end{array}$ & $\begin{array}{c}13196.2 \pm 2 \\
2272.5\end{array}$ & 11 & $\begin{array}{c}95 \\
7\end{array}$ \\
\hline eq $\% \mathrm{Ca}$ & $30-87$ & $57.8 \pm 10.1$ & 401 & $0-60$ & $\begin{array}{c}21.01 \pm \\
16.4\end{array}$ & 113 & $0-59.8$ & $\begin{array}{c}22.4 \pm 1 \\
4.7\end{array}$ & 99 & $0-62.61$ & $\begin{array}{c}22.4 \pm 1 \\
6.2\end{array}$ & 231 & $2.6-76.5$ & $37.9 \pm 16.1$ & 102 & $\begin{array}{l}5.14- \\
48.3\end{array}$ & $21.4 \pm 14.3$ & 11 & $\begin{array}{c}95 \\
7\end{array}$ \\
\hline $\mathrm{eq} \% \mathrm{Mg}$ & $3-43$ & $18.3 \pm 6.9$ & 401 & $0-68.2$ & $\begin{array}{l}19.8 \pm 1 \\
4.9\end{array}$ & 113 & $\begin{array}{l}6.6- \\
64.4\end{array}$ & $\begin{array}{c}27.3 \pm 1 \\
0.04\end{array}$ & 99 & $0-73.84$ & $\begin{array}{c}26.5 \pm 1 \\
2.7\end{array}$ & 231 & $\begin{array}{l}1.27- \\
61.26\end{array}$ & $18.9 \pm 9.5$ & 102 & $\begin{array}{l}0.8- \\
35.6\end{array}$ & $16.2 \pm 11.3$ & 11 & $\begin{array}{c}95 \\
7\end{array}$ \\
\hline eq $\% \mathrm{~K}$ & $0.6-19$ & $4.5 \pm 2.7$ & 401 & $0-46.8$ & $\begin{array}{c}18.6 \pm 9 \\
8\end{array}$ & 113 & $0-34.39$ & $\begin{array}{c}12.7 \pm 5 . \\
7\end{array}$ & 99 & $0-57.62$ & $\begin{array}{c}15.03 \pm \\
8.4\end{array}$ & 231 & $\begin{array}{l}1.51- \\
41.49\end{array}$ & $13.6 \pm 8.1$ & 102 & $\begin{array}{c}0.14- \\
9.5\end{array}$ & $2.9 \pm 2.8$ & 11 & $\begin{array}{c}95 \\
7\end{array}$ \\
\hline eq $\% \mathrm{Na}$ & $1-49$ & $19.33 \pm 6.9$ & 401 & $\begin{array}{l}7.6- \\
95.1\end{array}$ & $\begin{array}{c}40.6 \pm 1 \\
7.7\end{array}$ & 113 & $\begin{array}{l}3.26- \\
67.04\end{array}$ & $\begin{array}{c}37.6 \pm 1 \\
3.9\end{array}$ & 99 & $0-91.04$ & $\begin{array}{c}36.1 \pm 1 \\
8.3\end{array}$ & 231 & $\begin{array}{l}7.39- \\
72.89\end{array}$ & $29.5 \pm 12.8$ & 102 & $\begin{array}{l}35.5- \\
92.5\end{array}$ & $59.5 \pm 18.9$ & 11 & $\begin{array}{c}95 \\
7\end{array}$ \\
\hline $\begin{array}{l}\text { Major anions } \\
(\mu \mathrm{eg} / \mathrm{L})\end{array}$ & $\begin{array}{l}78.5- \\
6820\end{array}$ & $\begin{array}{c}912.9 \pm 824 \\
1\end{array}$ & 417 & $\begin{array}{c}9.8- \\
365.8\end{array}$ & $\begin{array}{c}101.7 \pm \\
63.5\end{array}$ & 93 & $\begin{array}{l}45.1- \\
722.6\end{array}$ & $\begin{array}{c}218.03 \\
\pm 103\end{array}$ & 91 & $\begin{array}{c}0.3- \\
1426.7\end{array}$ & $\begin{array}{c}213.4 \pm \\
174.8\end{array}$ & 168 & $\begin{array}{c}46.2- \\
1725.8\end{array}$ & $\begin{array}{c}220.7 \pm 228 \\
8\end{array}$ & 91 & $\begin{array}{l}1184.4- \\
76916\end{array}$ & $\begin{array}{c}20048.6 \pm 2 \\
6482.7\end{array}$ & 10 & $\begin{array}{c}87 \\
0\end{array}$ \\
\hline $\mathrm{Cl}(\mu \mathrm{eq} / \mathrm{L})$ & $\begin{array}{c}0- \\
3003.9 \\
8 \\
\end{array}$ & $\begin{array}{c}103.5 \pm 184 \\
1\end{array}$ & 422 & $0.7-155$ & $\begin{array}{c}37.4 \pm 3 \\
0.4\end{array}$ & 109 & $\begin{array}{c}3.8- \\
166.1\end{array}$ & $\begin{array}{c}38.1 \pm 2 \\
5.7\end{array}$ & 91 & $\begin{array}{l}0.28- \\
843.4\end{array}$ & $\begin{array}{c}50.2 \pm 8 \\
9.9\end{array}$ & 195 & $\begin{array}{l}1.27- \\
138.2\end{array}$ & $31.2 \pm 30.8$ & 93 & $\begin{array}{l}784.5- \\
71600\end{array}$ & $\begin{array}{c}15069.1 \pm 2 \\
2958.7\end{array}$ & 10 & $\begin{array}{c}92 \\
0\end{array}$ \\
\hline
\end{tabular}




\begin{tabular}{|c|c|c|c|c|c|c|c|c|c|c|c|c|c|c|c|c|c|c|c|}
\hline $\mathrm{SO}_{4}(\mu \mathrm{eq} / \mathrm{L})$ & $0-4380$ & $\begin{array}{c}113.1 \pm 298 \\
8\end{array}$ & 417 & $0-155.5$ & $\begin{array}{c}34.6 \pm 3 \\
9.9\end{array}$ & 93 & $\begin{array}{l}0.52- \\
112.4\end{array}$ & $\begin{array}{c}43.1 \pm 3 \\
5.1\end{array}$ & 91 & $\begin{array}{c}0- \\
231.01\end{array}$ & $\begin{array}{c}44.2 \pm 4 \\
4.3\end{array}$ & 168 & $0-558$ & $52.4 \pm 88.5$ & 92 & $\begin{array}{l}79.92- \\
18600\end{array}$ & $\begin{array}{c}3771.6 \pm 54 \\
35.8\end{array}$ & 10 & $\begin{array}{c}87 \\
1\end{array}$ \\
\hline $\mathrm{HCO}_{3}(\mu \mathrm{eq} / \mathrm{L})$ & $\begin{array}{c}46- \\
4539.8\end{array}$ & $\begin{array}{c}696.5 \pm 553 \\
8\end{array}$ & 434 & $0-229.1$ & $\begin{array}{c}30.4 \pm 3 \\
8.6\end{array}$ & 93 & $\begin{array}{c}4.9- \\
679.8\end{array}$ & $\begin{array}{c}128.9 \pm \\
105.1\end{array}$ & 97 & $\begin{array}{c}0- \\
1039.7\end{array}$ & $\begin{array}{c}112.9 \pm \\
122.5\end{array}$ & 199 & $\begin{array}{l}0.16- \\
1350\end{array}$ & $\begin{array}{c}139.03 \pm 19 \\
3.7\end{array}$ & 91 & $\begin{array}{c}232.6- \\
2976\end{array}$ & $\begin{array}{c}1198.2 \pm 10 \\
39.7\end{array}$ & 11 & $\begin{array}{c}92 \\
5\end{array}$ \\
\hline $\mathrm{eq} \% \mathrm{Cl}$ & $0-55$ & $10.8 \pm 7.4$ & 417 & $\begin{array}{l}1.8- \\
89.9\end{array}$ & $\begin{array}{c}38.3 \pm 2 \\
0.1\end{array}$ & 93 & $\begin{array}{c}2.4- \\
72.04\end{array}$ & $\begin{array}{c}18.3 \pm 1 \\
0.7\end{array}$ & 91 & $\begin{array}{l}1.48- \\
96.8\end{array}$ & $\begin{array}{c}25.9 \pm 2 \\
1.7\end{array}$ & 168 & $\begin{array}{l}0.84- \\
63.03\end{array}$ & $17.3 \pm 15.8$ & 91 & $\begin{array}{l}33.7- \\
93.1\end{array}$ & $66.5 \pm 18.5$ & 10 & $\begin{array}{c}87 \\
0\end{array}$ \\
\hline $\mathrm{eq} \% \mathrm{SO}_{4}$ & $0-65.4$ & $10.8 \pm 9.03$ & 417 & $0-82.6$ & $\begin{array}{c}31.5 \pm 2 \\
9.1\end{array}$ & 93 & $\begin{array}{c}0.58- \\
69.2\end{array}$ & $\begin{array}{c}20.7 \pm 1 \\
7.7\end{array}$ & 91 & $0-81.06$ & $\begin{array}{c}24.05 \pm \\
22.2\end{array}$ & 168 & 0-96.92 & $23.3 \pm 27.3$ & 91 & $\begin{array}{l}3.6- \\
37.3\end{array}$ & $21.8 \pm 13.5$ & 10 & $\begin{array}{c}87 \\
0\end{array}$ \\
\hline eq $\% \mathrm{HCO}_{3}$ & 29-99.3 & $78.4 \pm 10.4$ & 417 & $0-97.3$ & $\begin{array}{c}30.2 \pm 2 \\
5.4\end{array}$ & 93 & $\begin{array}{l}17.8- \\
94.1\end{array}$ & $\begin{array}{c}60.9 \pm 2 \\
2.02\end{array}$ & 91 & $0-96.82$ & $\begin{array}{c}49.9 \pm 2 \\
9.02\end{array}$ & 168 & $\begin{array}{l}0.09- \\
98.95\end{array}$ & $59.4 \pm 27.8$ & 91 & $\begin{array}{c}1.5- \\
29.03\end{array}$ & $11.7 \pm 10.4$ & 10 & $\begin{array}{c}87 \\
0\end{array}$ \\
\hline $\begin{array}{l}\mathbf{n}_{\text {total (by }} \\
\text { category) }=\end{array}$ & & & 7787 & & & 2087 & & & 854 & & & 045 & & & & & & 11 & \\
\hline
\end{tabular}

Source - Modified from Ríos-Villamizar et al. (2020b).

\begin{tabular}{lllll}
\hline Caminhos de Geografia $\quad$ Uberlândia-MG & v. 21, n. 78 & Dez/2020 & p. 211-226 & Página 219
\end{tabular}


The agreement among the data sets of black and white water categories is much closer and welldefined, even whether considering the respective annual variability, than those given for the hydrochemistry of clear waters. In contrast to the Amazonian black waters which show $\mathrm{pH}$-values below 5.5 and electrical conductivity less than $30 \mu \mathrm{S} \mathrm{cm}^{-1}$, the typical Amazonian white waters are characterized as carbonate waters (FURCH and JUNK, 1997), indicating richness in carbonates and calcium, pH ranging between 6.0 and 8.5, and electrical conductivity varying from 30 to $760 \mu \mathrm{S} \mathrm{cm}^{-1}$.

In our study 187 rivers and streams, corresponding to $49.2 \%$ of the total number analyzed do not fit into the 3 categories of Sioli. They occupy an intermediate position between the classical water types and have to be considered as mixed waters (RÍOS-VILLAMIZAR et al., 2020a). Among this group, we can separate three (3) other categories: Intermediate Type A (131 rivers and streams) that includes clear waters draining a mixture of different geological formations in the Guiana and Central Brazilian shields, Intermediate Type B (47 rivers and streams) that includes waters draining only sediments of Andean origin but presenting ecological characteristics intermediate between whitewater and blackwater; and the Brackish category (9 rivers and streams) consisting of waters affected by the tide on the Amazon estuary as well as some salty rivers in the Marañon and Ucayali drainage, which drain massive evaporates, show electrical conductivity above $400 \mu \mathrm{S} \mathrm{cm}^{-1}$, are very rich in $\mathrm{Na}$ and $\mathrm{Cl}$ and for this reason the proportions of these ions are up to $80-90 \%$ (Figures 2-3 and Table 1).

In spite of the overlaying areas between the two intermediate categories ( $A$ and $B$ ), the waters of the Intermediate Type A show much more variability than the Intermediate Type $\mathrm{B}$, at least by the $\mathrm{pH}$ and transparency values. It is probably explained because the waters of the Type A drain mostly a mixture of very heterogeneous older geological formations of the Precambrian and/or Paleozoic and/or Mesozoic Eras; but also more recent (Cenozoic) formations are observed, for instance, on the interfluves of the Negro and Branco rivers as well as in the upper parts of the Xingu and Araguaia rivers basins (RíOS-VILLAMIZAR et al. 2020b). The complete classification of Amazonian rivers and streams is presented in the Appendix according to the data re-analyzed.

The parameters used for the classification of river water depend upon the aim of the exercise. For example, a classification of quality for drinking water, quality for public health, or quality for aquatic productivity will use other parameters as an ecological classification. Our aim is a classification, which provides multiple information on ecological aspects of rivers and streams themselves, their connected wetlands, and their catchments. It is a landscape ecology approach according to Sioli (1984) and Junk et al. (2011). The key to the explanation of differences in hydrochemical parameters is the geology of the Amazon basin which in some areas is very complex (RíOS-VILLAMIZAR et al. 2020b).

As indicated by Junk et al. (2011), many tributaries of the Branco River transport a high load of suspended matter and have the appearance of whitewater rivers, however, chemical characteristics of these rivers indicate that they generally have low electrolyte status and a closer relationship to clearwater rivers. The Copatana river, a lower Jutaí river's left bank tributary, exhibit optical appearance of blackwater rivers, nonetheless, it shares water quality features such as electrical conductivity, hardness, $\mathrm{pH}$, and nutrient status, with whitewater rivers probably because, in the lower part, it receives a tributary Paraná coming directly from the Solimões river.

Even with his very limited data base, Sioli $(1949 ; 1957 ; 1968)$ and Sioli and Klinge (1962) already described others low-order Amazonian clear-water rivers such as Içana and Marauiá rivers, and some streams of the upper Negro river and Series of the Barreiras, Pará and Pebas Formation zones, which show much more variability, for instance the $\mathrm{pH}$-value for these rivers varies between 4.4-6.6. Specifically in the Pebas Formation zone the pH-value is in the range of 4.7-6.4 and the electrical conductivity varies between 3.7 and $171 \mu \mathrm{S} \mathrm{cm}^{-1}$. This maximum value of electrical conductivity probably is evidence that he identified some white water streams as clear water streams, just because of the high transparency, without considering the chemical parameters.

Sioli (1984) observed that "In January 1963, the Rio Marauiá, a left affluent of the middle Rio Negro, that rises in the mountain range of the Venezuelan border, had a water transparency of $c .2 \mathrm{~m}$. Suddenly the water rose some $0.30 \mathrm{~m}$ in 15 minutes and the transparency dropped to $0.45 \mathrm{~m}$; nevertheless, according with our study, it does not mean that a clearwater river that becomes turbid, as a result of some local rain in the mountain, turn into a whitewater stream, because the chemical parameters that depend on the geology of the catchment area, are relatively unaffected. 
The middle Tocantins river's major tributaries share some chemical characteristics such as electrical conductivity, $\mathrm{pH}$ and ionic composition with the classical white-water rivers, resembling the Tocantins river itself (RÍOS-VILLAMIZAR et al., 2020a). Since this basin is located far away from the Andes, this composition pattern is likely explained because the geology is characterized by the presence of sedimentary and effusive base rocks from the Parnaiba's sedimentary basin. The Mosquito Formation, which comprehends most of the southern right bank of the middle Tocantins river, is essentially made up of the basalt with a predominance of hilly terrain in this region and dendritic drainage in many tributaries. By the other hand, on the left bank, between the towns of Tocantinopolis and Imperatriz, there is a predominance of the Corda Formation, which is very calciferous (RíOS-VILLAMIZAR et al., 2014). Therefore, this evidence of a much greater chemical heterogeneity of the streams and small rivers is explained because of the geology of the Central Brazilian shield is very heterogeneous (FURCH and JUNK, 1997).

Possibly due to samples were collected at the lower section of the rivers, very near of the influence of the Amazon River's flood pulse, some Amazonian black-water bodies such as the Negro and Uatumã rivers in Brazil, Nanay river in Peru and some streams in Colombia can have ionic composition and/or $\mathrm{pH}$-value similar to white waters rivers and not like the typical Amazonian black waters rivers. The low electrical conductivity values can be responsible for this phenomenon because in electrolyte-poor waters, a little oscillation of $\mathrm{Ca}$ or $\mathrm{HCO}_{3}$ content can make a high variation of the respective percentage, which in the Solimões/Amazon river water would not affect the percentage in a noticeable way. The heterogeneous geology of the different tributaries may also be an explanation. For instance, the Jatapu river, an Uatumã river's lower tributary, crosses the Nova Olinda/Carboniferous Formation and probably this fact is responsible for alterations in the physico-chemical characteristics of the Uatumã River's lower part.

Although the brownish color appearance, caused principally by the inflow of blackwater streams especially from the left-hand side, the Parauari-Maués Açú river headwaters are located in a region of the northern part of the central brazilian archaic shield, draining Carboniferous/Paleozoic and Cretaceous/Mesozoic Formations and usually yellow latosols (BRINGEL et al., 1984), resembling the pattern of the Curuá-Una river basin (JUNK et al., 1981; DARWICH, 1982). These rivers are classified in the Intermediate type A category.

Some rivers such as Jutaí and Bóia (a middle Jutaí river's left bank tributary), and the Purus river tributaries such as Ituxi, Tapaua and Ipixuna rivers, draining more or less leached paleo-sediments originating from the Andes, show intermediate composition between white and black water (JUNK et al., 2011). The results of the single samples that were collected around the lower part of the Tefé, Manacapuru and Urubu river basins, do not allow getting a general statement about their chemical category. It is remarkable that the Tefé river configuration presents higher and lower percentages of $\mathrm{K}$ and $\mathrm{Na}$, respectively, than the classical blackwater rivers.

In general terms, the Paleo-várzea (mid-early Pleistocene) of the Purus river is older than the Solimões one (mid-late Pleistocene), and this may explain why the waters of some Purus river's tributaries (e.g., Ituxi, Tapaua and Ipixuna rivers) are poorer in carbonates than the Solimões tributaries, but both are richer in $\mathrm{Na}$ and $\mathrm{K}$ than $\mathrm{Ca}$ and Mg (QUEIROZ et al., 2009; IRION et al., 2010). Depending on the sampling date, white water rivers like Putumayo/lça, Caquetá/Japurá, Javari and Purus can have intermediate chemical characteristics between white and black water or just closer relationship to the ionic composition and/or content of blackwater rivers.

The data of the Barcarena region, Guajará and Marajó bays waters, at the Amazon estuary, show high percent of $\mathrm{Na}$ and $\mathrm{Cl}$ probably because of the sea water influence, small proportions of $\mathrm{Ca}$ and $\mathrm{K}$, the $\mathrm{Mg}$ and $\mathrm{K}$ percentages are similar to whitewater rivers and the $\mathrm{Ca}$ percentages are similar to blackwater rivers. The Barcarena region streams show a cation composition between white and clear water rivers. Near the coast, electric conductivity can raise up to $1000 \mu \mathrm{S} \mathrm{cm}^{-1}$ (TANCREDI et al., 1991) probably because of entrance of marine water and/or aerial salt deposition. 
Even so, we can generalize the available information as follows: The most characteristic water type is the Amazon whitewater deriving from the Andes. The water of the main stem becomes diluted from about 120-200 $\mu \mathrm{S} \mathrm{cm}^{-1}$ near the Andes to $40-70 \mu \mathrm{S} \mathrm{cm}-1$ at Santarem by blackwater and clearwater tributaries (GIBBS, 1967, 1972; OLTMAN, 1968; STALLARD and EDMOND, 1983; SANTOS and RIBEIRO, 1988; DUQUE et al., 1997), but it continues to be a turbid, nearly neutral, relatively electrolyte-rich water dominated by carbonates of alkali earth metals. The importance of the total amount and relationship of alkali and alkali-earth metals and carbonates for the classification of Amazonian waters was first documented by Furch and Klinge (1978), and Furch and Junk (1980) and can be considered as an essential additional chemical parameter for the classification of Amazonian water types. If we do this, some rivers, draining the carboniferous stripes at the lower Amazon, where many dissolved substances can be found in higher values than usual (SIOLI, 1968), such as some tributaries of the Ji-Paraná, Tapajós, Xingu and Tocantins/Araguaia rivers, the Tocantins River itself, and some rivers and streams near Monte Alegre region in Para State; as well as some rivers of the Andean/Pre-Andean zone such as Zongo river in the upper Madeira basin (ORE-HYBAm), and Carbón, Salvación, Serjali, Shilive, Azul, Cupodnoe, Nusiniscato and Araza rivers, and the streams Mabe, Santa Isidora, Aguas Calientes and Quitari in the Peruvian region (RÍOS-VILLAMIZAR et al., 2020a) have to be considered as whitewater rivers despite of a low load of suspended sediments. 105 rivers $(27.6 \%)$ of the investigated Rivers fall in the white water category.

A similarly characteristic water type is the Negro River black water which, originated on the Precambrian shield of the northern region of the Amazon basin, is a typical representative of the Amazonian black waters (FURCH and JUNK, 1997). Its transparent red-brown colour originates from a high content of dissolved humic substances which is about ten times higher than in the Solimões/Amazon River, the water is poor in nutrients and electrolytes with dominance of sodium among the major cations, presenting low alkalinity. The $\mathrm{pH}$ and electrical conductivity values are less than 5.5 and $30 \mu \mathrm{S} \mathrm{cm}^{-1}$, respectively. 76 rivers (20\%) of the investigated rivers fall in the black water category.

The rivers of the Sioli's clear water type have their upper catchments in the Central Brazilian and Guiana archaic/Pre-Cambrian shields and are characterized by pH-values that vary between 5.3 and 7.2, electrical conductivity is in the range of $5.1-53.6 \mu \mathrm{S} \mathrm{cm}^{-1}$, the water transparency can reach up to $355 \mathrm{~cm}$ or still higher; but transparency values less than $50 \mathrm{~cm}$ are also common in these rivers. We consider the total amount and relationship of alkali and alkali-earth metals and carbonates as a more stable and stronger parameter for the water classification than the amount of suspended solids and transparency. Sioli's clear water rivers "sensu stricto" are represented by only 12 rivers, corresponding to $3.2 \%$ of the total.

The rivers of Intermediate Type A category are characterized by $\mathrm{pH}$, electrical conductivity and transparency values that are in the range of $3.75-9.20,1.18-140.89 \mu \mathrm{S} \mathrm{cm} \mathrm{cm}^{-1}$ and $15.5-294 \mathrm{~cm}$, respectively. This category includes clear water rivers and streams "sensu lato" which drain a mixture of different geological formations in the Guiana and Central Brazilian shields and are represented by 131 rivers and streams, corresponding to $34.5 \%$ of the total.

The rivers of Intermediate Type $\mathrm{B}$ category are characterized by $\mathrm{pH}$, electrical conductivity and transparency values that are in the range of $5.2-7.2,0.01-190.7 \mu \mathrm{sm}^{-1}$ and $4-150 \mathrm{~cm}$, respectively. This category includes waters draining sediments of Andean and Pre-Andean origin and presenting ecological characteristics intermediate between whitewater and blackwater (RíOS-VILLAMIZAR et al., 2020a). This category is represented by 47 rivers and streams, corresponding to $12.4 \%$ of the total.

The rivers of the Brackish water type are characterized by $\mathrm{pH}$, electrical conductivity and transparency values that are in the range of $5.2-8.5,358.3-7171.9 \mu \mathrm{S} \mathrm{cm}^{-1}$ and $5-60 \mathrm{~cm}$, respectively. This category consists of coastal waters with marine influence as well as some salty rivers in the Marañon and Ucayali drainage which show increased salinity and are dominated by sodium and chloride. This category is represented by 9 rivers and streams, corresponding to $2.4 \%$ of the total. The updated classification is given in Figure 6 . 
Figure 6 - The distribution of river types in the Amazon basin.

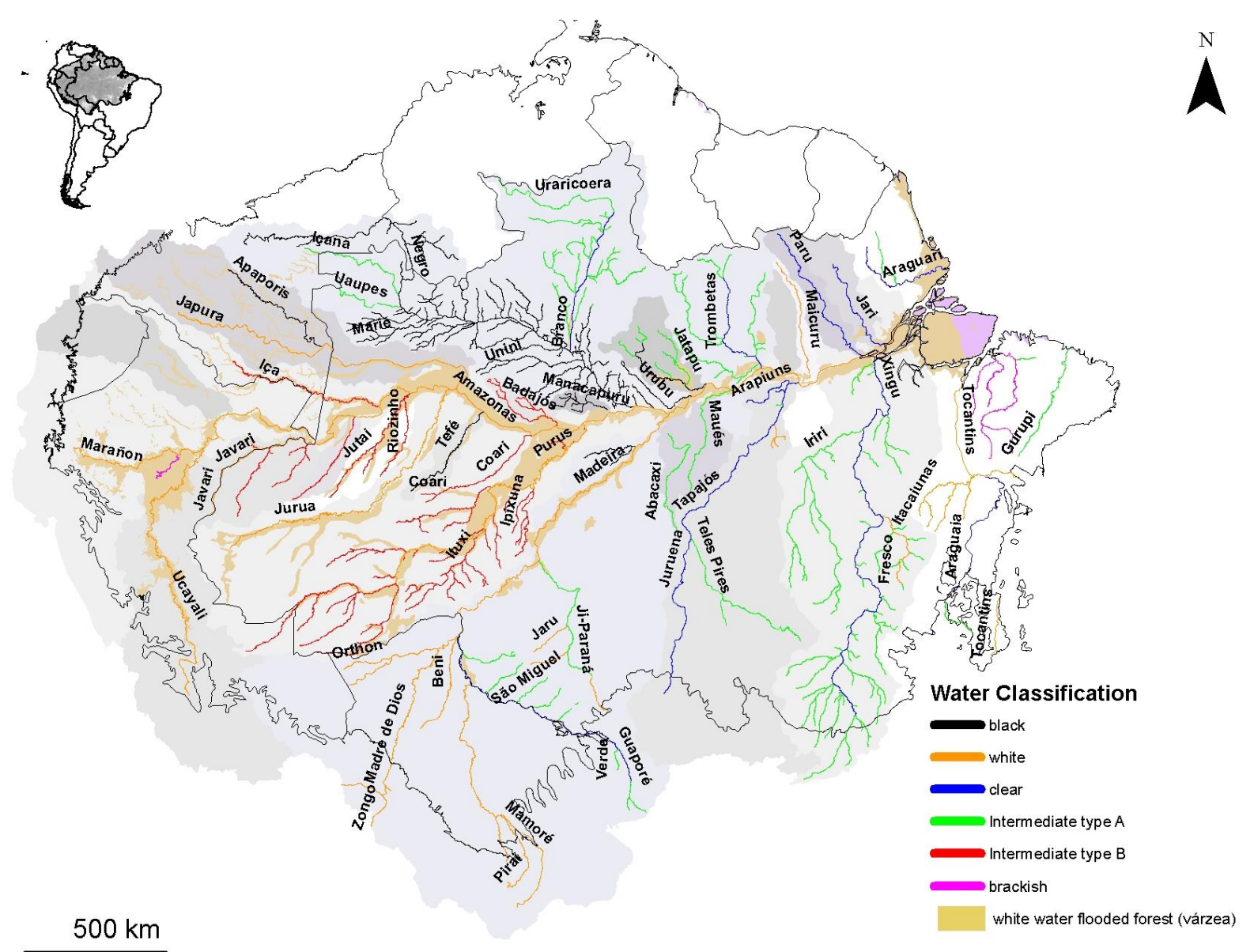

Source - Updated from Ríos-Villamizar et al. (2020a).

\section{CONCLUSIONS}

The combination of the parameters $\mathrm{pH}$, electrical conductivity, the amount and relationship between alkali and alkali-earth metals and carbonates allow distinguishing the three classical water types (white, black and clear) and the Intermediate Types A and B. A general statement about the brackish water type pattern cannot yet be given because of the scarcity of the available data. The distribution of alkali and alkaline-earth metals and major anions is especially useful for the distinction of whitewater, blackwater and clearwater categories. Higher variability is shown by water bodies that not fit inside these three classic categories. Despite some adjustments by including the amount and relationship between alkali and alkali-earth metals and carbonates into Sioli's general classification, his approach continues to be valid for ecological and management purposes. However, we have to live with the fact that the physico-chemical diversity of Amazonian waters is large and increases with decreasing river order, because small streams indicate local geological differences better than large rivers, which represent the conditions of large catchment areas. Therefore, many rivers and streams have to be considered as "mixed waters" resulting from the influence of lower order tributaries with different physico-chemical properties of their waters. Even though the large quantity of information was utilized in this study, hydrochemical data are scarce for many low to medium order rivers and a detailed classification covering the entire Amazon basin is not yet possible. Thus, it is necessary to continue collecting water samples principally in unstudied streams and rivers throughout the Amazon basin and the Amazon estuary in order to continuously update the databases. 
A classification system of Amazonian wetlands already uses hydrochemical parameters for the differentiation between the floodplains of large nutrient-rich whitewater and nutrient-poor blackwater rivers. These water types represent the upper and the lower end of the fertility gradient. The wetlands differ in species composition and productivity of herbaceous plants and trees, which are used together with hydrological parameters for the characterization of macrohabitats. Low fertility of blackwater river floodplains show low resilience against disturbance and strong limitations of human use in contrast to nutrient-rich whitewater river floodplains. The hydrochemical classification, updated in this paper, indicates in lower order tributaries the existence of many transitional hydrochemical stages and the change in water quality in these systems between rainy and dry seasons. These differences have not yet been considered in the general Brazilian and Amazonian wetland classification systems. They require additional research efforts for vegetation inventories to allow a specific macrohabitat classification. According to Ríos-Villamizar et al. (2020a), only on this basis these wetlands can become included in the general wetland classification system and respective management recommendations can be formulated for their sustainable management.

\section{ACKNOWLEDGMENTS}

This work was funded by "CAPES/CNPq-IEL Nacional-Brasil", Nuclei Excellency Support Projects (PRONEX) "Tipologias Alagáveis (CNPq/FAPEAM)", INPA/Max-Planck, Ecology, Monitoring and Sustainable Use of Wetlands Group (MAUA/CDAM/PELD/MAUA), Climate and Environment Program at the Brazilian National Institute for Amazonian Research (INPA/UEA), Programa de Apoio à Fixação de Doutores no Amazonas - FIXAM/AM (grant number: 062.01319/2014) and Programa de Apoio à Participação em Eventos Científicos e Tecnológicos - PAPE from the Fundação de Amparo à Pesquisa do Estado do Amazonas - FAPEAM/SECTI/AM, and the Instituto Nacional de Ciência e Tecnologia em Áreas Úmidas (INCT-INAU-UFMT). The authors are grateful to the Chemistry Laboratory (CPCRH/INPA) for water analyses assistance. We thank the anonymous reviewers for the comments and suggestions they provided. The first author is "Bolsista CAPES/BRASIL".

\section{REFERENCES}

APHA, AWWA and WEF. Standard Methods for the Examination of Water and Wastewater, 21st Ed. American Public Health Association, Washington, D.C. 2005.

BRINGEL, S.R.B.; SANTOS, U.M.; RIBEIRO, M.N.G.; BERGAMIN FILHO, H. Bacia do rio ParauariMaués-Açu. Aspectos químicos devidos às alterações hidrológicas da bacia. Acta Amazonica, v. 14 (1-2), p. 77-85, 1984.https://doi.org/10.1590/1809-43921984142085

DARWICH, A. J. Estudos limnológicos na represa hidrelétrica de Curuá-Una (Santarém-PA). Dissertação (Mestrado) - Manaus: INPA/FUA. 1982.

DUQUE. S. R.; RUIZ. J. E.; GÓMEZ. J.; ROESSLER. E. Limnología. In: IGAC. (Ed.) Zonificación ambiental para el Plan modelo Colombo-Brasilero (eje Apaporis-Tabatinga): PAT. Bogotá: Editorial Linotipia, 1997. p. 71-134.

FIGUEIREDO, R. O.; MARKEWITZ, D.; DAVIDSON, E. A.; SCHULER, A. E.; WATRIN, O.S.; SILVA, P. S. Land-use effects on the chemical attributes of low-order streams in the eastern Amazon. J. Geophys. Res., v. 115, G04004, 2010. https://doi.org/10.1029/2009JG001200

FURCH, K.; KLINGE, H. Towards a regional characterization of the Biogeochemistry of alkali and alkali-earth metals in northern south America. Acta Cient. Venez., v. 29, p. 434-444, 1978.

FURCH, K. Hydrogeochemistry of Amazonian freshwaters along the transamazônica in Brazil. Zbl. $\begin{array}{lllll}\text { Geol. Paläont, Teil I }(9 / 10), & \text { p. }\end{array}$ https://doi.org/10.1127/zbl geol pal 1/1985/1986/1485

FURCH, K.; JUNK, W.J. Water chemistry and macrophytes of creeks and rivers in southern 
Amazonia and the central Brazilian Shield. In: FURTADO II. (Ed). Tropical Ecology and Development. Part 2. The international Society of tropical Ecology. Kuala Lumpur, 1980, p. 771-796.

FURCH, K., JUNK, W.J. Physicochemical Conditions in the Floodplains. In: JUNK, W.J. (Ed). The Central Amazon Floodplain: Ecology of a Pulsing System. Berlin Heidelberg: Springer-Verlag, 1997. p. 69-108. https://doi.org/10.1007/978-3-662-03416-3 4

GAILLARDET, J.; DUPRÉ, B.; ALLÈGRE, C.J; NÉGREL, P. Chemical and physical denudation in the Amazon River Basin. Chem. Geol., v. 142(3-4), p. 141-173, 1997. https://doi.org/10.1016/S00092541(97)00074-0

GIBBS, R. J. The geochemistry of the Amazon River system: Part I. The factors that control the salinity and the composition and concentration of the suspended solids. Geol. Soc. Am. Bull., v. 78, p. 1203-1232, 1967. https://doi.org/10.1130/0016-7606(1967)78[1203:TGOTAR]2.0.CO;2

GIBBS, R.J. Water chemistry of the Amazon River. Geochim. Cosmochim. Acta, v. 36, p. 1061-1066, 1972. https://doi.org/10.1016/0016-7037(72)90021-X

IRION, G.; DE MELLO, J.A.S.N.; MORAIS, J.; PIEDADE, M.T.F.; JUNK, W.J.; GARMING, L. Development of the Amazon valley during the Middle to Late Quaternary: sedimentological and climatological observations. In: JUNK, W.J.; PIEDADE, M.T.F.; WITTMANN, F.; SCHÖNGART, J.; PAROLIN, P. (Eds). Central Amazonian floodplain forests: ecophysiology, biodiversity and sustainable management. Berlin: Springer Verlag, 2010. p. 27-42. https://doi.org/10.1007/978-90-481$\underline{8725-62}$

JUNK, W.J.; ROBERTSON, B.A; DARWICH, A.J.; VIEIRA, I. Investigações limnológicas e ictiológicas em Curuá-Una, a primeira represa hidrelétrica na Amazônia Central. Acta Amazonica, v. 11(4), p. 689-716, 1981. https://doi.org/10.1590/1809-43921981114689

JUNK, W.J.; PIEDADE, M.T.F.; SCHÖNGART, J.; COHN-HAFT, M.; ADENEY, J.M.; WITTMANN, FA. Classification of Major Naturally-Occurring Amazonian Lowland Wetlands. Wetlands, v. 31, p. 623-640, 2011. https://doi.org/10.1007/s13157-011-0190-7

JUNK, W.J.; PIEDADE, M.T.F.; SCHÖNGART, J.; WITTMANN, FA. A classification of major natural habitats of Amazonian white-water river floodplains (várzeas). Wetlands Ecol. Manage., v. 20, p. 461475, 2012. https://doi.org/10.1007/s11273-012-9268-0

OLTMAN, R.E. Reconnaissance investigations of the discharge and water quality of the Amazon River. U.S. Geological Survey. Circular 552. Washington, D.C. 16p. 1968. https://doi.org/10.3133/cir552

ORE-HYBAM. Database of the Environmental Research Observatory (Geodynamical, hydrological and biogeochemical control of erosion/alteration and material transport in the Amazon basin). www.ore-hybam.org. Accessed in: 21 August 2012.

QUEIROZ, M. M. A.; HORBE, A.M.C.; SEYLER, P.; MOURA, C. A. V. Hidroquímica do rio Solimões na região entre Manacapuru e Alvarães - Amazonas - Brasil. Acta Amazonica, v. 39(4), p. 943 - 952 , 2009. https://doi.org/10.1590/S0044-59672009000400022

RAMOS, J.F.F.; TANCREDI, A.C.N.S. Geoquímica de águas e sedimentos do baixo rio Tapajós e afluentes: Resultados preliminares. Anais do IV Simpósio de Geologia da Amazônia, SBG, Belém, p. 278-280, 1994.

RICHEY, J.E.; VICTORIA, R. L.; HEDGES, J.I.; DUNNE, T.L.A.; MARTINELLI, L. MERTES.; J. ADAMS. Pre-LBA Carbon in the Amazon River Experiment (CAMREX) Data. Data set. Available online [http://daac.ornl.gov] from Oak Ridge National Laboratory Distributed Active Archive Center, Oak Ridge, Tennessee, U.S.A, 2008. https://doi.org/10.3334/ORNLDAAC/904

RÍOS-VILLAMIZAR, E.A.; ADENEY, J.M.; JUNK, W.J.; PIEDADE, M.T.F. Physicochemical features of 
Amazonian water typologies for water resources management. IOP Conf Ser: Earth Environ Sci., v. 427, 012003, 2020a. https://doi.org/10.1088/1755-1315/427/1/012003

RÍOS-VILLAMIZAR, E.A.; ADENEY, J.M.; PIEDADE, M.T.F; JUNK, W.J. New insights on the classification of major Amazonian river water types. Sustainable Water Resources Management, v.6, 83, 2020b. https://doi.org/10.1007/s40899-020-00440-5

RÍOS-VILLAMIZAR, E. A. Química da água para a classificação dos rios e igarapés da bacia amazônica. Tese (Doutorado) - Manaus: INPA/UEA. 2013.

RíOS-VILLAMIZAR. E. A.; PIEDADE. M. T. F.; DA COSTA J. G.; ADENEY. J. M.; JUNK. W. J. Chemistry of different Amazonian water types for river classification: a preliminary review. WIT Transactions on Ecology and The Environment. v. 178. p. 17-28. 2014. https://doi.org/10.2495/WS130021

RÍOS-VILLAMIZAR, E. A.; PIEDADE, M. T. F.; JUNK, W. J. Tipologias de águas em áreas úmidas da Bacia Amazônica: uma revisão enfatizando a classificação dos rios e igarapés. In: FERREIRA, S. J. F.; SILVA, M.L.; PASCOALOTO, D. (Org.). Amazônia das águas: qualidade, ecologia e educação ambiental. Manaus, Brasil: Editora Valer/Fapeam/Inpa, 1a ed, v.1, 2016. p. 175-191.

SANTOS, U. M.; RIBEIRO, M. N. G. A hidroquímica do rio Solimões-Amazonas. Acta Amazonica, v. 18(3-4), p. 145-172, 1988. https://doi.org/10.1590/1809-43921988183172

SILVA, M.S.R.; RÍOS-VILLAMIZAR, E.A.; BRANDÃO DA CUNHA, H.; FONSECA MIRANDA, S.Á.; FERREIRA, S.J.F.; BRINGEL, S.R.B.; GOMES, N.A.; PASCOALOTO, D.; SILVA, L.M. A Contribution to the Hydrochemistry and Water Typology of the Amazon River and its tributaries. Caminhos de Geografia (UFU. Online), v.20, p. 360-374, 2019. https://doi.org/10.14393/RCG207246295

SIOLI, H. O Rio Cuparí. I. Topografia e hidrografia. Bol. Técn. Inst. Agr. Norte, Belém, v. 17, p. 1-54, 1949.

SIOLI, H. Beitraege zur regionalen Limologie des Amazonasgebietes IV. Archiv., f. Hydrobiol., v. 53, p. 161-222, 1957.

SIOLI, H. Hydrochemistry and geology in the Brazilian Amazon region. Amazoniana, v. 1(3), p. 267277, 1968.

SIOLI, $\mathrm{H}$. The Amazon and its main affluents: Hydrography, morphology of the river courses, and river types. In: SIOLI, H. (Ed). The Amazon - Limnology and landscape ecology of a mighty tropical river and its basin. Dordrecht, Netherlands: Junk, 1984. p. 127-166. https://doi.org/10.1007/978-94-009$\underline{6542-35}$

SIOLI, H.; KLINGE, H. Solos, tipos de vegetação e águas na Amazônia. B. Mus. Paraen. Emílio Goeldi, nova sér., Avulsa, v. 1, p. 27-41, 1962.

STALLARD, R. F.; EDMOND, J. M. Geochemistry of the Amazon basin: 2. The influence of the geology and weathering environment on the dissolved load. J. Geophys. Res. v. 88. p. 9671-9688. 1983. https://doi.org/10.1029/JC088iC14p09671

VENTICINQUE, E.; FORSBERG, BR.; BARTHEM, R.B.; PETRY, P.; HESS, L.; MERCADO, A. et al. An explicit GIS-based river basin framework for aquatic ecosystem conservation in the Amazon. Earth Syst Sci Data., v. 8, p. 651-61, 2016. https://doi.org/10.5194/essd-8-651-2016

Recebido em: 20/03/2020

Aceito para publicação em: 12/08/2020 